\title{
Technical Details of Redo Aortic Valve Replacement using St. Jude Medical Mechanical Prosthesis in a Patient with Thrombosed Aortic Mechanical Prosthesis: A Video Presentation
}

\author{
Niwin George ${ }^{1}$, Lakshmi Kumari Sankhyan ${ }^{2}$, Shikha Goja ${ }^{1}$, Sumanth Raghuprakash ${ }^{1}$, Shradha Gupta ${ }^{1}$, Shweta Sharma ${ }^{1}$, Niraj Nirmal \\ Pandey $^{1}$, Ujjwal K. Chowdhury ${ }^{1^{*}}$ \\ ${ }^{1}$ Cardiothoracic Centre, All India Institute of Medical Sciences, New Delhi \\ ${ }^{2}$ Department of Cardiothoracic and Vascular Surgery, All India Institute of Medical Sciences, Bilaspur, Himachal Pradesh
}

*Corresponding Author: Ujjwal Kumar Chowdhury, Professor Department of Cardiothoracic and Vascular Surgery AIIMS, New Delhi 110029, INDIA

Received Date: September 21, 2021; Accepted Date: November 19, 2021; Published Date: November 29,2021

Citation: Ujjwal Kumar Chowdhury, Niwin George, Lakshmi Kumari Sankhyan, Shikha Goja, Sumanth Raghuprakash., et all (2021). Technical Details of Redo Aortic Valve Replacement using St. Jude Medical Mechanical Prosthesis in a Patient with Thrombosed Aortic Mechanical Prosthesis: A Video Presentation. J. Clinical Cardiology and Cardiovascular Interventions, 4(18); DOI:10.31579/2641-0419/224

Copyright: (C) 2021 Ujjwal Kumar Chowdhury, This is an open-access article distributed under the terms of the Creative Commons Attribution License, which permits unrestricted use, distribution, and reproduction in any medium, provided the original author and source are credited.

\section{Abstract \\ Current consensus guidelines of the AHA and ESC, uniformly recommend either type of prosthetic valve for patients aged 60 to 70 years and mechanical prosthesis for patients aged less than 60 years \\ Keywords: redo aortic valve; femoral arterio-venous cannulation prior; echocardiographically}

\section{Introduction}

Current consensus guidelines of the AHA and ESC, uniformly recommend either type of prosthetic valve for patients aged 60 to 70 years and mechanical prosthesis for patients aged less than 60 years. [1-4] These recommendations are based on the results of 4 randomized controlled trials that demonstrated no significant difference in late survival. [2-6] Two of these trials compared mechanical and bioprosthetic valve models implanted in 1970s and 1980s. [5-7] The other 2 trials included patients undergoing aortic valve replacement. Contemporary data are limited to small single center studies. [1,2,8-10]

Valve replacement in young adults entails a choice between a mechanical prosthesis with risks of anticoagulation-related bleeding/thrombosis versus bioprosthesis necessitating eventual reoperation.

Despite usage of carbon pyrolite and central flow design of St. Jude Medical mechanical prosthetic valve, thromboembolism and anticoagulant induced haemorrhage after surgery continue to account for $75 \%$ of all valve-related complications. [11,12]

Thrombolysis of thrombosed St. Jude mechanical valves is safe and is the preferred first choice of treatment in the absence of other contraindications for anticoagulation. [11-15] Cinefluoroscopy is the preferred method for diagnosis and follow-up of St. Jude thrombosis in our institution. [11] Doppler echocardiography and cinefluoroscopy have complimentary role in assessing prosthetic valve function during thrombolytic therapy. [5-8,16-19]

Patients who do not respond within 48-72 hours should be referred for surgery because these patients may have tissue ingrowth obstructing the prosthetic valve (Panus formation) and usually do not respond to continued thrombolytic treatment. Explantation of the prosthetic valves during redo surgical procedures present formidable surgical challenges in many instances.

We present here-in a 48 year-old male patient diagnosed to have a chronic thrombosed St. Jude Medical aortic valve prosthesis, with failed thrombolysis, who underwent explantation of the thrombosed aortic prosthesis and re-replacement of the mitral valve using another $21 \mathrm{~mm} \mathrm{St}$. Jude Medical mechanical prosthesis. The technical details of explantation and re-replacement procedure without causing injury to the cardiac chambers, and great vessels have been discussed in detail. Postoperative recovery was uneventful.

\section{Surgical Techniques}

Following systemic heparinisation, elective right femoral arteriovenous cannulation is done using long femoral arterial and venous cannulae (Edwards Lifesciences LLC, One Edwards Way, Irvine, CA, USA).

Under cardiopulmonary bypass, secondary median sternotomy is performed with the heart decompressed on bypass. The pericardium 
overlying the aorta, right ventricular outflow tract and superior vena cava is dissected.

An 18-Fr sump suction vent is placed over the main pulmonary artery for further decompression of the heart to facilitate dissection. The superior caval vein is being dissected and cannulated directly using an angled metal tipped venous cannula and drained directly into the oxygenator. The intrapericardial inferior caval vein is dissected and looped for later occlusion.

After aortic cross-clamping, an oblique horse-shoe shaped aortotomy was performed in between stay sutures $1.5 \mathrm{~cm}$ above the sinus of the right coronary artery stopping about $1 \mathrm{~cm}$ above the midpoint of the noncoronary sinus. Myocardial protection was achieved by integrated myocardial protection using direct ostial St. Thomas (II) based cold blood cardioplegia (4:1) and topical cardiac cooling using ice cold saline. Successive doses of cardioplegia were repeated every 30 minutes.

Two stay sutures of 2-0 Ethibond (Johnson and Johnson Ltd., Ethicon, LLC, San Lorenzo, USA) are placed over the prosthetic mitral annulus to facilitate later explantation of the aortic prosthesis.

An incision is made on the aortic prosthetic ring using a No.11 scalpel blade. The prosthetic valve is detached from the aortic annulus by a combined sharp and blunt dissection.

A small right angle forceps is insinuated within the opening to facilitate explantation of the aortic prosthesis. The prosthetic valve is explanted by incising the prosthetic fibrous capsule on both aortic and ventricular surface. Extreme precautions are taken not to cause aorto ventricular discontinuity. Precautions are also taken not to dislodge the thrombus contained within the prosthetic mitral valve.

Re-replacement of the mitral valve is done using a $21 \mathrm{~mm}$ St. Jude mechanical aortic prosthesis (St. Jude Medical; St Jude Medical; St. Paul, MN, USA) and interrupted 2-0 Ethibond mattress suture. The aortotomy is closed in two layers using 4-0 polypropylene sutures (Johnson and Johnson Ltd., Ethicon, LLC, San Lorenzo, USA).

\section{Results}

The patient was weaned off cardiopulmonary bypass on dopamine $5 \mu \mathrm{g} / \mathrm{kg} / \mathrm{min}$ and nitriglycerine $0.5 \mu \mathrm{g} / \mathrm{kg} / \mathrm{min}$. He was extubated after 6 hours. At 12 months follow-up, he is in New York Heart Association functional class I with left ventricular ejection fraction of 0.60 , in normal sinus rhythm. Echocardiographically, the mean systolic left ventricle-toaortic pressure gradient was $8 \mathrm{mmHg}$, no aortic regurgitation and there was no paravalvular / cuff leakage.

\section{Video Presentation}

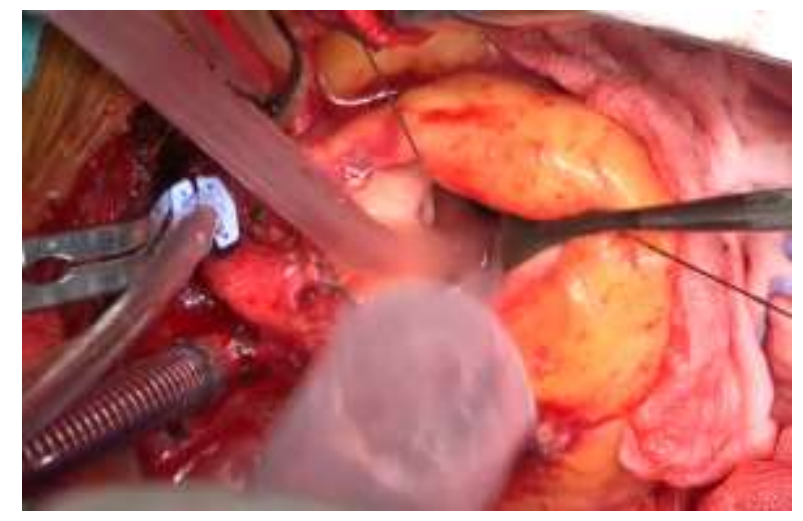

\section{Conclusions}

Elective institution of cardiopulmonary bypass through femoro-femoral arterio-venous cannulation prior to sternotomy prevents accidental injury to the cardiac chambers and great vessels during sternal entry. Pulmonary artery venting and cannulation of the superior vena cava further facilitates dissection of the cardiac chambers without causing injury. Placement of two stay sutures on the prosthetic annulus and intracapsular dissection greatly facilitates explantation without causing aorto ventricular discontinuity.

\section{Declaration of conflicting interests}

The author(s) declared no potential conflicts of interest with respect to the research, authorship and/or publication of the article.

\section{Funding}

The authors received no financial support for the research, authorship and/or publication of this article.

\section{References}

1. Nishimura RA, Otto CM, Bonow RO, et al. AHA/ACC guidelines for management of patients with valvular heart disease: A report of the ACC/AHA Task Force on Practice Guidelines. Circulation 2014; 129: 521-643.

2. Nakano K, Hirahara N, Motomura N, et al. Current status of cardiovascular surgery in Japan, 2013 and 2014: A report based on the Japan Cardiovascular Surgery Database. 4. Valvular heart surgery. Gen Thorac Cardiovasc Surg 2017; 66: 13 - 18.

3. Vahanian A, Alfieri O, Andreotti F, et al. Guidelines on management of valvular heart disease. Eur Heart J 2012; 33: 2451 2496.

4. Bonow RO, Carabello BA, Chatterjee K, et al. ACC/AHA 2006 Guidelines for management of patients with valvular heart disease: A report of the ACC/AHA Task Force on Practice Guidelines. J Am Coll Cardiol. 2006;48: e1-148.

5. Oxenham H, Bloomfield P, Wheatley DJ, et al. Twenty-year comparison of Bjork-Shiley mechanical heart valve with porcine bioprostheses. Heart. 2003;89:715-721.

6. Hammermeister K, Sethi GK, Henderson WG, et al. Outcomes 15years after valve replacement with mechanical versus bioprosthetic valve: final report of the Veterans Affairs randomized trial. J Am Coll Cardiol. 2000;36:1152-1158.

7. Stassano P, Tommaso LD, Monaco M, et al. A prospective randomized evaluation of mechanical versus biological valves in patients aged 55 to 70 years. J Am Coll Cardiol 2009;54:18621868.

8. Kaneko T, Cohn LH, Aranki SF. Tissue valve is the preferred option for patients aged 60 and older. Circulation 2013; 128: 1365 $-1371$.

9. Rahimtoola SH. Choice of prosthetic heart valve in adults: an update. J Am Coll Cardiol. 2010;55:2413-2426.

10. Grunkemeier GL, Starr A, Rahimtoola SH. Clinical performance of prosthetic heart valves. In: Schlant RA, Alexander RW, editors. Hurst's The Heart. New York, NY: McGraw-Hill, 1998:18511866.

11. Chowdhury UK, Sharma P, Sankhyan LK, Hasijs S, Narang R, Manikalaivani. Thromboembolic and bleeding complications following St. Jude Medical Valve Replacement. Ann Short reports 2018; 1: 1009.

12. Bodnar E. A critical assessment of thrombosis and embolism reporting methods. Butchart, EG Bodnar, E eds. Thrombosis, embolism and bleeding 1992; 476-484.

13. Salem DN, Stein PD, Al-Ahmad A, et al. Antithrombotic therapy in valvular heart disease: native and prosthetic; the Seventh ACCP 
Conference on Anthrombotic and Thrombolytic Therapy. Chest 2004; 126(suppl): 457S-482S.

14. John S, Ravikumar E, Jairaj PS, Chowdhury UK, et al. Valve replacement in young patient with rheumatic heart disease. Review of twenty-year experience. J Thorac Cardiovasc Surg 1990;99(4):631-638.

15. Stein PD, Alpert JS, Copeland J, et al. Antithrombotic therapy in patients with mechanical and biological prosthetic heart valves. Chest. 1992; 102(suppl):445S-454S.

16. Czer LSC, Weiss M, Bateman TM, et al. Fibrinolytic therapy of St. Jude valve thrombosis under guidance of digital cinefluoroscopy. J Am Coll Cardiol 1985; 5: 1244-1249.
17. Castaneda-Zuniga $\mathrm{W}$, Nocoloff $\mathrm{D}$, Jorgensen $\mathrm{C}$, et al. In vivo radiographic appearance of the St. Jude valve prosthesis. Radiology 1980; 134: 775-776.

18. Mehlman D. A guide to the radiographic identification of prosthetic heart valves: An addendum. Circulation 1984; 69: 102105.

19. Chafizadeh ER, Zoghbi WA. Doppler echocardiographic assessment of the St. Jude Medical prosthetic valve in the aortic position using the continuity equation. Circulation 1991; 83: 213 223.
This work is licensed under Creative Commons Attribution 4.0 License

DOI: $10.31579 / 2641-0419 / 224$

Ready to submit your research? Choose Auctores and benefit from:

$>$ fast, convenient online submission

$>$ rigorous peer review by experienced research in your field

$>$ rapid publication on acceptance

$>$ authors retain copyrights

$>$ unique DOI for all articles

$>$ immediate, unrestricted online access

At Auctores, research is always in progress.

Learn more https://auctoresonline.org/journals/clinical-cardiology-andcardiovascular-interventions 